\title{
SKALA LIKERT DALAM SELEKSI KARYAWAN BARU DENGAN METODE FUZZY TSUKAMOTO BERBASIS WEB (STUDI KASUS: PT TELKOM AKSES AREA SAMARINDA)
}

\author{
M. Irwan Ukkas ${ }^{1}$, Hanifah Ekawati ${ }^{2}$, dan Tendi Riandi ${ }^{3)}$ \\ ${ }^{1,3}$ Teknik Informatika, STMIK Widya Cipta Dharma Samarinda \\ ${ }^{2}$ Manajemen Informatika, STMIK Widya Cipta Dharma Samarinda \\ ${ }^{1,2,3}$ Jl. Prf. M. Yamin No.25, Samarinda, 75123 \\ E-mail : irwan212@yahoo.com ${ }^{1)}$, hanifahekawati.mus88@ gmail.com ${ }^{2}$, tendiriandi.me@ gmail.com ${ }^{3)}$
}

\begin{abstract}
ABSTRAK
PT Telkom Akses adalah anak perusahaan Telkom yang bergerak pada bidang bisnis penyediaan dan pengelolaan infrakstruktur jaringan fiber di indonesia. Semakin berkembangnya Telkom Akses maka diperlukan sumber daya manusia lebih banyak. Oleh karena itu Telkom Akses melakukan rekrut karyawan baru melalui divisi HCM (Human Capital Management). Sebelum melakukan rekrut karyawan, telah dibuat skema seleksi calon karyawan agar mendapatkan sumber daya manusia sesuai dengan visi dan misi perusahaan. Untuk mempermudah proses seleksi karyawan baru di Area Kota Samarinda maka pada penelitian ini merancang sebuah sistem untuk seleksi karyawan baru berbasis web menggunakan skala likert dengan metode Fuzzy Tsukamoto. Metode tsukamoto digunakan untuk melakukan fuzzyfikasi nilai-nilai fuzzy pada skala likert. Pengembangan sistem dalam penelitian ini menggunakan metode sistem penunjang keputusan, tahapannya yaitu (1) Intelegensi, (2) desain, (3) pemilihan, dan (4) Implementasi. Untuk pemodelan sistem menggunakan diagram alir dan sitemap. Sistem diimplementasikan menggunakan bahasa pemrograman PHP, sublime text 3 sebagai webeditor, XAMPP sebagai webserver local, basis data MySQL dan codeigniter sebagai framework. Hasil dari implementasi skala likert seleksi karyawan baru berbasis web menggunakan metode fuzzy tsukamoto menghasilkan aplikasi penilaian karyawan baru yang dapat membantu divisi HCM area samarinda dalam penilaian hasil tes, dan memberikan laporan rekomendasi hasil seleksi karyawan baru kepada pimpinan perusahaan di area.
\end{abstract}

Kata Kunci : Fuzzy Tsukamoto, Skala Likert, Seleksi Karyawan

\section{PENDAHULUAN}

Logika fuzzy sangat berguna untuk menyelesaikan banyak permasalahan dalam berbagai bidang yang biasanya memuat derajat ketidakpastian. Likert Scale digunakan untuk mengukur sikap dan pendapat. Penerapan Likert Scale pada Logika Fuzzy memunculkan indikator skala yang di konversikan pada angka-angka fuzzy, karena berupa variabel sehingga bisa di ukur tingkat kebenarannya dengan logika fuzzy.

PT Telkom Akses Area Samarinda merupakan salah satu perusahaan terbesar yang bergerak dalam bisnis penyediaan layanan konstruksi dan pengelolaan infrastruktur jaringan. PT Telkom Akses Area Samarinda memiliki divisi Human Capital Management (HCM). Divisi ini menangani proses seleksi penerimaan karyawan baru di PT Telkom Akses Area Samarinda. Proses penerimaannya yaitu melakukan analisis pada masing-masing bagian yang sedang membutuhkan karyawan baru, dan kemudian mencari karyawan baru dengan membuka lowongan pekerjaan. Selanjutnya, melakukan seleksi karyawan dengan cara wawancara dan psikotes.

Proses seleksi penerimaan karyawan baru yang dilakukan pada PT Telkom Akses Area Samarinda, masih belum maksimal dikarenakan terlalu banyak membutuhkan waktu yang lama untuk perhitungan nilai hasil seleksi karyawan. Sehingga sering terjadi kesalahan terhadap penilaian hasil seleksi karyawan. Hal ini menyebabkan kinerja pihak Human Capital Management (HCM) PT Telkom Akses Area Samarinda, tidak efisien dan efektif.

Dari permasalahan tersebut, maka dapat dilakukan suatu penelitian dengan judul "Implementasi Skala Likert Seleksi Karyawan Baru Dengan Metode Fuzzy Tsukamoto Berbasis Web (Studi Kasus Pada PT Telkom Akses Area Samarinda)" hal ini bertujuan agar membantu PT Telkom Akses Area Samarinda melakukan pengambilan keputusan dalam menyeleksi karyawan baru dan mengurangi kesalahan dalam penilaian hasil seleksi karyawan baru..

\section{RUANG LINGKUP PENELITIAN}

Permasalahan difokuskan pada:

1. Sistem yang dibangun merupakan aplikasi website.

2. Berikut uraian komponen penilaian Seleksi penerimaan karyawan baru yang telah di implementasikan di perusahaan, yaitu sebagai berikut: 
1) Tes Psikotes,

1 Tes Kemampuan Dasar,

2 Tes Deret Angka,

3 Tes Analogi Verbal,

4 Tes Penalaran Analitik.

2) Tes Fisik,

3) Tes Ketinggian.

3. Aplikasi perhitungan seleksi karyawan ini bersifat statis pada kriteria dan sub kriteria.

4. Hasil seleksi berupa perangkingan calon karyawan pada sistem Administrator. Kemudian hasilnya dilaporkan kepada pimpinan sebagai penentu keputusan (decision maker) dalam bentuk laporan.

\section{METODE PENELITIAN} in

Berikut disajikan teknik dan tahapan dari penelitian

\subsection{Metode Pengumpulan Data}

Metode perolehan data dengan studi lapangan ini terbagi menjadi 2 (dua), yaitu:

1. Teknik Observasi

Teknik pengumpulan data dengan cara mengadakan pengamatan langsung ke tempat melalui studi kelayakan terhadap objek yang ingin diteliti dan dilakukan dalam situasi yang khusus, serta untuk pencapaian akhir dengan menganalisa data dan membuat laporan hasil dari pelaksanaan kegiatan observasi.

2. Wawancara

Pengumpulan data dengan wawancara ini dilakukan untuk mencari data dan informasi tentang hal-hal yang dibutuhkan dalam penelitian. Wawancara dilakukan dengan staff HCM PT. Telkom Akses Kota Samarinda yang dijadikan objek penelitian. Wawancara dilakukan lebih menitik beratkan bagaimana standar prosedur dalam penerimaan karyawan serta standar perusahaan dalam menentukan karyawan khususnya dalam pembobotan pada prioritas kriteria, sub kriteria dan alternatif.

\subsubsection{Studi Pustaka}

Yaitu dengan mempelajari buku-buku literatur yang berhubungan dengan judul dan mengambil sebagai bahan pembanding atau dasar pembahasan lanjut serta untuk memperoleh landasan-landasan teori dari sistem yang akan di kembangkan.

\subsection{Metode Pengembangan Sistem}

Metodelogi pengembangan sistem yang dibangun menggunakan metode pengembangan sistem pendukung keputusan, karena dianggap cocok untuk pengembangan sistem yang akan dibuat., tahapan tersebut, diantaranya:

1. Tahap Intelligence

2. Tahap Design

3. Tahap Choice

4. Tahap Implementation

\section{HASIL PENELITIAN DAN PEMBAHASAN}

Dalam membangun sistem ini memerlukan beberapa tahapan diantaranya:

1. Tahap Intelligence

Dalam memenuhi kebutuhan untuk meningkatkan produktifitas pekerjaan maka PT Telkom Akses perlu melakukan rekrut karyawan baru. sebelum merekrut karyawan baru, ada proses seleksi yang bertujuan untuk menyesuaikan kebutuhan perusahaan dengan sumber daya manusia sesuai peraturan perusahaan. Selain itu, proses seleksi diharapkan bisa menjadi acuan untuk mendapatkan sumber daya manusia yang terbaik.

Proses seleksi karyawan baru yang sesuai dengan alur perusahaan memunculkan kriteria untuk ditetapkan. Kriteria yang ditetapkan dalam kasus ni adalah pertama, tes psikotes terdiri atas tes kemampuan dasar, tes deret angka, tes analogi verbal, tes penalaran analitik. Kedua, tes fisik dan ketiga, tes ketinggian.

Pada penelitian ini akan ada 2 level pengguna, yaitu user dan admin. Level user berfungsi hanya untuk melihat data yang berada pada aplikasi, sedangkan level admin berfungsi untuk menginput, mengedit dan melihat data.

2. Tahap Design

Setelah fase inteleegensi kemudian dimulai fase perancangan dengan menentukan dan mengumpulkan data-data yang akan digunakan dalam penelitian ini.

1) Penentuan Kriteria Penilaian

Dalam penelitian ini terdapat 3 kriteria yang akan digunakan dalam perhitungan sistem yaitu tabel 1 sampai 8.

Tabel 1. Kriteria Penilaian

\begin{tabular}{|l|l|}
\hline \multicolumn{1}{|c|}{ Kriteria Utama } & \multicolumn{1}{c|}{ Sub Kriteria } \\
\hline Tes Psikotes & Tes Kemampuan Dasar, \\
& Tes Deret Angka, \\
& Tes Analogi Verbal, \\
& Tes Penalaran Analitik. \\
\hline Tes Fisik & - \\
\hline Tes Ketinggian & - \\
\hline
\end{tabular}

2) Likert Scale

Tabel 2. Skala Likert Tes Psikotes

\begin{tabular}{|c|c|}
\hline Interval Penilaian & Metode Pengukuran \\
\hline $81-100$ & Sangat Disarankan \\
\hline $61-80$ & Disarankan \\
\hline $41-60$ & Cukup \\
\hline $21-40$ & Kurang Disarankan \\
\hline $0-20$ & Sangat Kurang Disarankan \\
\hline
\end{tabular}

Tabel 3. Skala Likert Tes Kemampuan Dasar \begin{tabular}{|l|l}
\hline Interval Penilaian & Metode Pengukuran
\end{tabular}

\begin{tabular}{|c|c|}
\hline $81-100$ & Sangat Memuaskan \\
\hline $61-80$ & Memuaskan \\
\hline $41-60$ & Cukup \\
\hline $21-40$ & Kurang Memuaskan \\
\hline $0-20$ & Sangat Kurang Memuaskan \\
\hline
\end{tabular}


Tabel 4. Skala Likert Tes Deret Angka

\begin{tabular}{|c|c|}
\hline Interval Penilaian & Metode Pengukuran \\
\hline $81-100$ & Sangat Memuaskan \\
\hline $61-80$ & Memuaskan \\
\hline $41-60$ & Cukup \\
\hline $21-40$ & Kurang Memuaskan \\
\hline $0-20$ & Sangat Kurang Memuaskan \\
\hline
\end{tabular}

Tabel 5. Skala Likert Tes Analogi Verbal Interval Penilaian $\quad$ Metode Pengukuran

\begin{tabular}{|c|c|}
\hline $81-100$ & Sangat Memuaskan \\
\hline $61-80$ & Memuaskan \\
\hline $41-60$ & Cukup \\
\hline $21-40$ & Kurang Memuaskan \\
\hline $0-20$ & Sangat Kurang Memuaskan \\
\hline
\end{tabular}

Tabel 4.6 Skala Likert Tes Penalaran Analitik \begin{tabular}{|c|c|c|}
\hline Interval Penilaian & Metode Pengukuran
\end{tabular}

\begin{tabular}{|c|c|}
\hline $81-100$ & Sangat Memuaskan \\
\hline $61-80$ & Memuaskan \\
\hline $41-60$ & Cukup \\
\hline $21-40$ & Kurang Memuaskan \\
\hline $0-20$ & Sangat Kurang Memuaskan \\
\hline
\end{tabular}

\section{Tabel 7. Skala Likert Tes Fisik}

\begin{tabular}{|c|c|}
\hline Interval Penilaian & Metode Pengukuran \\
\hline $81-100$ & Sangat Disarankan \\
\hline $61-80$ & Disarankan \\
\hline $41-60$ & Kurang Disarankan \\
\hline $21-40$ & Tidak Disarankan \\
\hline $0-20$ & Sangat Tidak Disarankan \\
\hline
\end{tabular}

Tabel 8. Skala Likert Tes Ketinggian

\begin{tabular}{|c|c|}
\hline Interval Penilaian & Metode Pengukuran \\
\hline $81-100$ & Sangat Disarankan \\
\hline $61-80$ & Disarankan \\
\hline $41-60$ & Kurang Disarankan \\
\hline $21-40$ & Tidak Disarankan \\
\hline $0-20$ & Sangat Tidak Disarankan \\
\hline
\end{tabular}

3) Variable dan fungsi pada Fuzzy Tsukamoto (Fuzzyfikasi)

Proses fuzzyfikasi merupakan perhitungan nilai crisp atau nilai input menjadi derajat keanggotaan. Perhitungan dalam proses fuzzyfikasi berdasarkan batas-batas fungsi keanggotaan. Pada penelitian ini terdapat fungsi keanggotaan (membership function) yang diterapkan pada masing-masing kriteria dan di tentukan pada skala likert. Berikut ini adalah fungsi keanggotaan himpunan fuzzy input dan output:

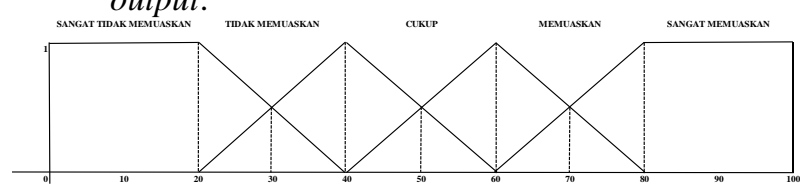

Gambar 1. Himpunan Fuzzy Input

Fungsi Keanggotaan :

$$
\begin{aligned}
& \mu[x, 20,40]=\left\{\begin{array}{lr}
1 ; & x \leq 20 \\
(40-x) /(40-20) ; & 20 \leq x \leq 40 \\
0 ; & x \geq 40
\end{array}\right. \\
& \mu[x, 20,40,60]=\left\{\begin{array}{lr}
0 ; & x \leq 20 \text { atau } x \geq 60 \\
(x-20) /(40-20) ; & 20 \leq x \leq 40 \\
(40-x) /(60-40) ; & 40 \leq x \leq 60
\end{array}\right. \\
& \mu[x, 40,60,80]=\left\{\begin{array}{lr}
0 ; & \text { atau } x \geq 80 \\
(x-40) /(60-40) ; & 40 \leq x \leq 60 \\
(60-x) /(80-60) ; & 60 \leq x \leq 80
\end{array}\right. \\
& \mu[x, 60,80]=\left\{\begin{array}{lr}
0 ; & x \leq 60 \\
(x-60) /(80-60) ; & 60 \leq x \leq 80 \\
1 ; & x \geq 80
\end{array}\right.
\end{aligned}
$$

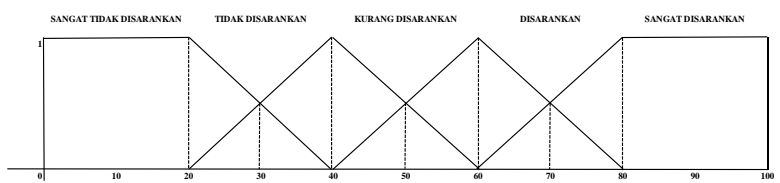

Gambar 2. Himpunan Fuzzy Output

Fungsi Keanggotaan :

$$
\begin{aligned}
& \mu[x, 20,40]=\left\{\begin{array}{lr}
1 ; & x \leq 20 \\
(40-x) /(40-20) ; & 20 \leq x \leq 40 \\
0 ; & x \geq 40
\end{array}\right. \\
& \mu[x, 20,40,60]=\left\{\begin{array}{lr}
0 ; & 20 \leq x \leq 40 \\
(x-20) /(40-20) ; & 40 \leq x \leq 60 \\
(40-x) /(60-40) ; & x \leq 40 \text { atau } x \geq 80
\end{array}\right. \\
& \mu[x, 40,60,80]=\left\{\begin{array}{lr}
0 ; \\
(x-40) /(60-40) ; & 60 \leq x \leq 60 \\
(60-x) /(80-60) ; & x \leq 60
\end{array}\right. \\
& \mu[x, 60,80]=\left\{\begin{array}{lr}
0 ; \\
(x-60) /(80-60) ; & 60 \leq x \leq 80 \\
1 ; & x \geq 80
\end{array}\right.
\end{aligned}
$$

4) Aturan Fuzzy

Aturan atau rule fuzzy dapat dilihat pada tabel 4.9 dan tabel 4.10, dimana dibuat dengan menggunakan fungsi "If-Then" dan menggunakan operator " $A N D$ " sehingga semua kondisi aturan harus terpenuhi untuk mendapatkan output. Pada penelitian ini digunakan 2 rule fuzzy, pertama rule untuk output Tes Psikotes, kedua rule untuk mendapatkan output Hasil Tes.

Tabel 9 Aturan Fuzzy Tes Psikotes

\begin{tabular}{|c|c|c|c|c|c|}
\hline NO & $\begin{array}{c}\text { Tes } \\
\text { Kemampuan } \\
\text { Dasar }\end{array}$ & $\begin{array}{c}\text { Tes Deret } \\
\text { Angka }\end{array}$ & $\begin{array}{c}\text { Tes } \\
\text { Analogi } \\
\text { Verbal }\end{array}$ & $\begin{array}{c}\text { Tes } \\
\text { Penalaran } \\
\text { Analitik }\end{array}$ & Keterangan \\
\hline 1 & $\begin{array}{c}\text { Sangat } \\
\text { Memuaskan }\end{array}$ & $\begin{array}{c}\text { Sangat } \\
\text { Memuaskan }\end{array}$ & $\begin{array}{c}\text { Sangat } \\
\text { Memuaskan }\end{array}$ & $\begin{array}{c}\text { Sangat } \\
\text { Memuaskan }\end{array}$ & $\begin{array}{c}\text { Sangat } \\
\text { Disarankan }\end{array}$ \\
\hline 2 & $\begin{array}{c}\text { Sangat } \\
\text { Memuaskan }\end{array}$ & Memuaskan & Cukup & Cukup & $\begin{array}{c}\text { Sangat } \\
\text { Disarankan }\end{array}$ \\
\hline 3 & Memuaskan & Memuaskan & Memuaskan & Memuaskan & Disarankan \\
\hline 4 & Memuaskan & Memuaskan & Cukup & Cukup & Disarankan \\
\hline 5 & Cukup & Cukup & Cukup & Cukup & $\begin{array}{c}\text { Kurang } \\
\text { Disarankan }\end{array}$ \\
\hline 6 & Cukup & Cukup & $\begin{array}{c}\text { Tidak } \\
\text { Memuaskan }\end{array}$ & $\begin{array}{c}\text { Tidak } \\
\text { Memuaskan }\end{array}$ & $\begin{array}{c}\text { Kurang } \\
\text { Disarankan }\end{array}$ \\
\hline 7 & $\begin{array}{c}\text { Tidak } \\
\text { Memuaskan }\end{array}$ & $\begin{array}{c}\text { Tidak } \\
\text { Memaskan }\end{array}$ & $\begin{array}{c}\text { Tidak } \\
\text { Memuaskan }\end{array}$ & $\begin{array}{c}\text { Tidak } \\
\text { Memuaskan }\end{array}$ & $\begin{array}{c}\text { Tidak } \\
\text { Disarankan }\end{array}$ \\
\hline 8 & $\begin{array}{c}\text { Tidak } \\
\text { Memuaskan }\end{array}$ & $\begin{array}{c}\text { Tidak } \\
\text { Memuaskan }\end{array}$ & $\begin{array}{c}\text { Tidak } \\
\text { Memuaskan }\end{array}$ & $\begin{array}{c}\text { Sangat } \\
\text { Tidak } \\
\text { Memuaskan }\end{array}$ & $\begin{array}{c}\text { Tidak } \\
\text { Disarankan }\end{array}$ \\
\hline 9 & $\begin{array}{c}\text { Sangat Tidak } \\
\text { Memuaskan }\end{array}$ & $\begin{array}{c}\text { Sangat } \\
\text { Tidak } \\
\text { Memuaskan }\end{array}$ & $\begin{array}{c}\text { Sangat } \\
\text { Tidak } \\
\text { Memuaskan }\end{array}$ & $\begin{array}{c}\text { Cukup } \\
\text { Cungat } \\
\text { Tidak } \\
\text { Disarankan }\end{array}$ \\
\hline 10 & $\begin{array}{c}\text { Sangat Tidak } \\
\text { Memuaskan }\end{array}$ & $\begin{array}{c}\text { Sangat } \\
\text { Tidak } \\
\text { Memuaskan }\end{array}$ & $\begin{array}{c}\text { Sangat } \\
\text { Tidak } \\
\text { Memuaskan }\end{array}$ & $\begin{array}{c}\text { Sangat } \\
\text { Tidak } \\
\text { Memuaskan }\end{array}$ & $\begin{array}{c}\text { Sangat } \\
\text { Tidak } \\
\text { Disarankan }\end{array}$ \\
\hline
\end{tabular}

Tabel 10 Aturan Fuzzy Hasil Tes

\begin{tabular}{|c|c|c|c|c|}
\hline NO & Tes Psikotes & Tes Fisik & $\begin{array}{c}\text { Tes } \\
\text { Ketinggian }\end{array}$ & Keterangan \\
\hline 1 & $\begin{array}{c}\text { Sangat } \\
\text { Disarankan }\end{array}$ & $\begin{array}{c}\text { Sangat } \\
\text { Disarankan }\end{array}$ & $\begin{array}{c}\text { Sangat } \\
\text { Disarankan }\end{array}$ & Sangat Disarankan \\
\hline 2 & $\begin{array}{c}\text { Sangat } \\
\text { Disarankan }\end{array}$ & Disarankan & $\begin{array}{c}\text { Sangat } \\
\text { Disarankan }\end{array}$ & Sangat Disarankan \\
\hline 3 & Disarankan & Disarankan & Disarankan & Disarankan \\
\hline 4 & Disarankan & $\begin{array}{c}\text { Kurang } \\
\text { Disarankan }\end{array}$ & $\begin{array}{c}\text { Disarankan } \\
\text { Kurang }\end{array}$ & Disarankan \\
\hline 5 & $\begin{array}{c}\text { Kurang } \\
\text { Disarankan }\end{array}$ & $\begin{array}{c}\text { Kurang } \\
\text { Disarankan }\end{array}$ & $\begin{array}{c}\text { Kurank } \\
\text { Disarankan }\end{array}$ & Kurang Disarankan \\
\hline 6 & $\begin{array}{c}\text { Kurang } \\
\text { Disarankan }\end{array}$ & $\begin{array}{c}\text { Tidak } \\
\text { Disarankan }\end{array}$ & $\begin{array}{c}\text { Kurang } \\
\text { Disarankan }\end{array}$ & Kurang Disarankan \\
\hline 7 & $\begin{array}{c}\text { Tidak } \\
\text { Disarankan }\end{array}$ & $\begin{array}{c}\text { Tidak } \\
\text { Disarankan }\end{array}$ & $\begin{array}{c}\text { Tidak } \\
\text { Disarankan }\end{array}$ & Tidak Disarankan \\
\hline 8 & $\begin{array}{c}\text { Tidak } \\
\text { Disarankan }\end{array}$ & $\begin{array}{c}\text { Sangat Tidak } \\
\text { Disarankan }\end{array}$ & $\begin{array}{c}\text { Tidak } \\
\text { Disarankan }\end{array}$ & Tidak Disarankan \\
\hline
\end{tabular}




\begin{tabular}{|c|c|c|c|c|}
\hline 9 & $\begin{array}{c}\text { Sangat Tidak } \\
\text { Disarankan }\end{array}$ & $\begin{array}{c}\text { Tidak } \\
\text { Disarankan }\end{array}$ & $\begin{array}{c}\text { Sangat Tidak } \\
\text { Disarankan }\end{array}$ & $\begin{array}{c}\text { Sangat Tidak } \\
\text { Disarankan }\end{array}$ \\
\hline 10 & $\begin{array}{c}\text { Sangat Tidak } \\
\text { Disarankan }\end{array}$ & $\begin{array}{c}\text { Sangat Tidak } \\
\text { Disarankan }\end{array}$ & $\begin{array}{c}\text { Sangat Tidak } \\
\text { Disarankan }\end{array}$ & $\begin{array}{c}\text { Sangat Tidak } \\
\text { Disarankan }\end{array}$ \\
\hline
\end{tabular}

3. Tahap Choice

1) Flowchart Sistem

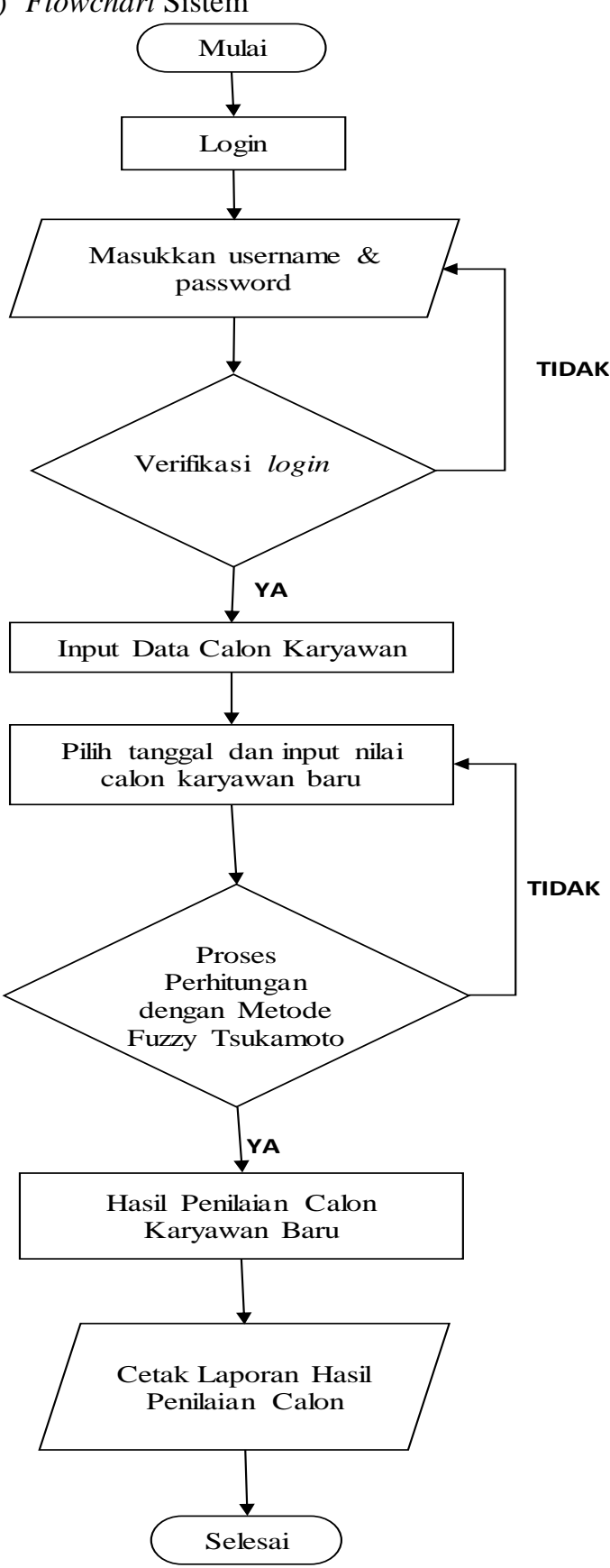

Gambar 3. Flowchart Sistem

2) Flowchart Perhitungan Likert Scale dengan Fuzzy Tsukamoto

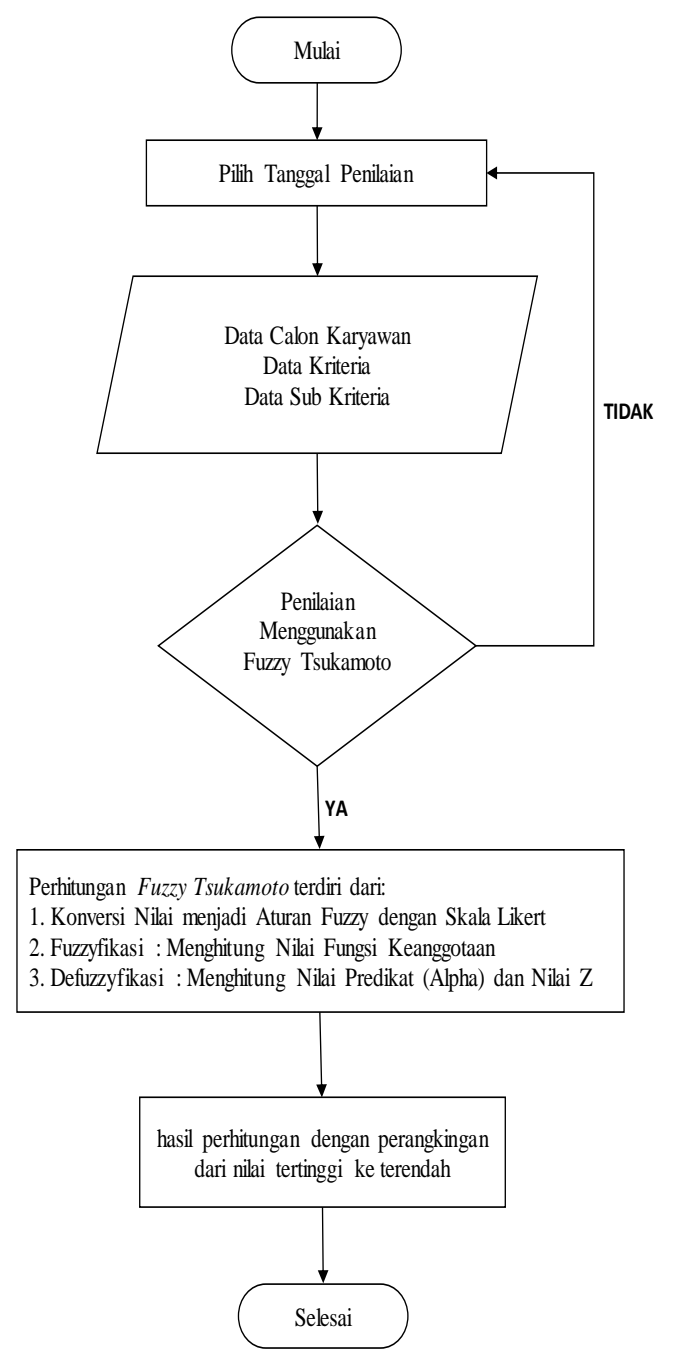

Gambar 4. Flowchart Perhitungan Fuzzy Tsukamoto

3) Sitemap Admin

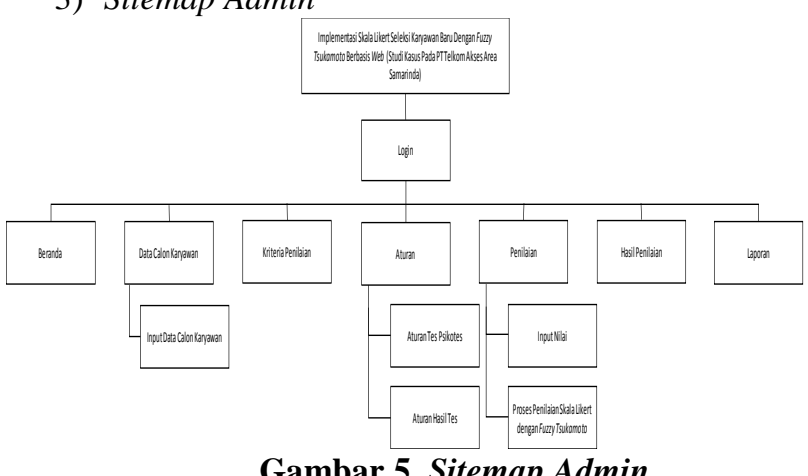

5. IMPLEMENTASI

Berikut disajikan hasil implementasi dari penelitin ini 5.1 Halaman Login

Halaman login merupakan halaman yang pertama muncul pada saat mulai menjalankan aplikasi. Halaman login berfungsi untuk memberikan keamanan di dalam sistem. User terlebih dahulu harus mengisi username dan password yang benar sebelum masuk ke dalam sistem. 


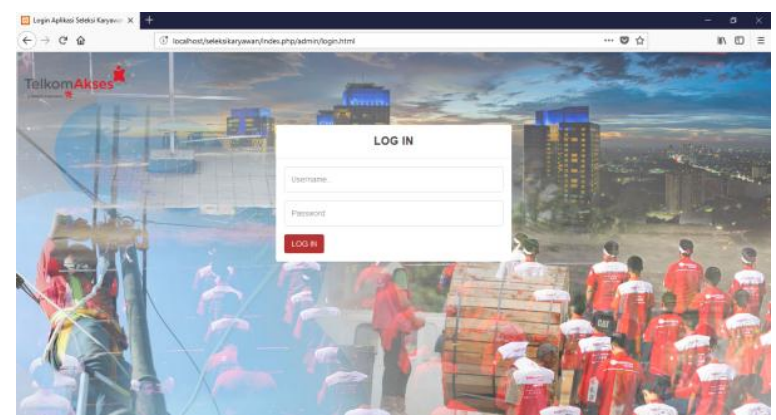

Gambar 6. Tampilan Halaman Login

\subsection{Halaman Beranda}

Setelah pengguna berhasil memasukkan username dan password, muncul halaman beranda dari aplikasi. Dalam halaman beranda terdapat beberapa menu yang dapat dioperasikan oleh user. User dapat mengoperasikan semua menu yang ada di dalam aplikasi yaitu menu Data Calon Karyawan, menu Kriteria Penilaian, menu Aturan, menu Penilaian menu Hasil Penilaian, dan menu Laporan.

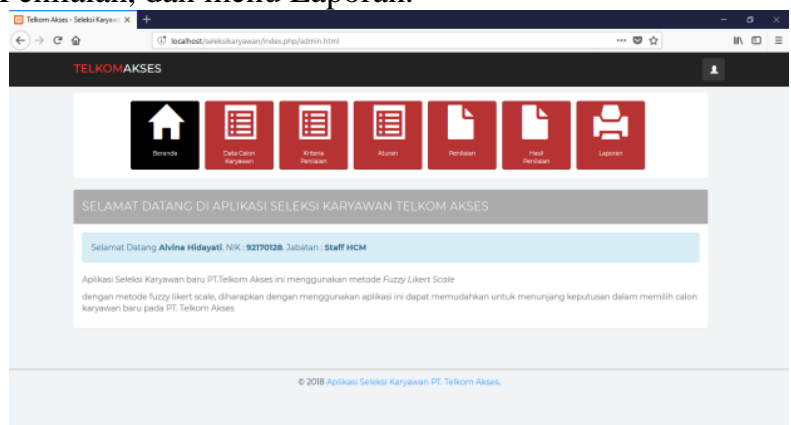

\section{Gambar 7. Tampilan Halaman Beranda}

\subsection{Halaman Data Calon Karyawan}

Halaman Data Calon Karyawan terdapat tombol tambah data dan menampilkan data yang berisikan no, nik, nama, jenis kelamin, tempat \& tanggal lahir, pendidikan terakhir \& jurusan dan aksi yang bisa di sunting maupun dihapus.

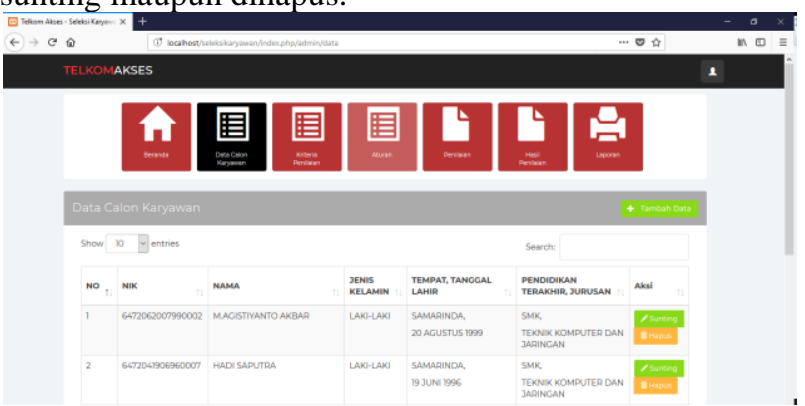

\section{Gambar 8. Tampilan Halaman Data Calon} Karyawan

Halaman tambah data calon karyawan merupakan halaman untuk menambah data calon karyawan baru. Pada halaman ini terdapat form input untuk NIK, nama, pilihan jenis kelamin, kota lahir, tanggal lahir, pendidikan terakhir, jurusan.

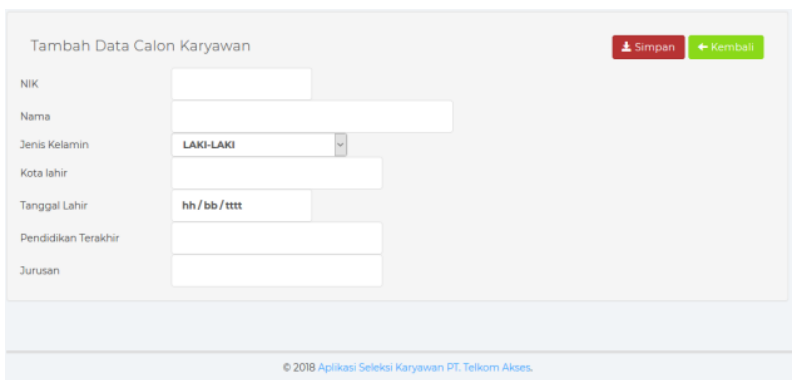

Gambar 9. Tampilan Halaman Tambah Data Calon

\subsection{Halaman Kriteria} Karyawan

Halaman Data Kriteria menampilkan data yang berisikan no, kriteria, dan subkriteria.

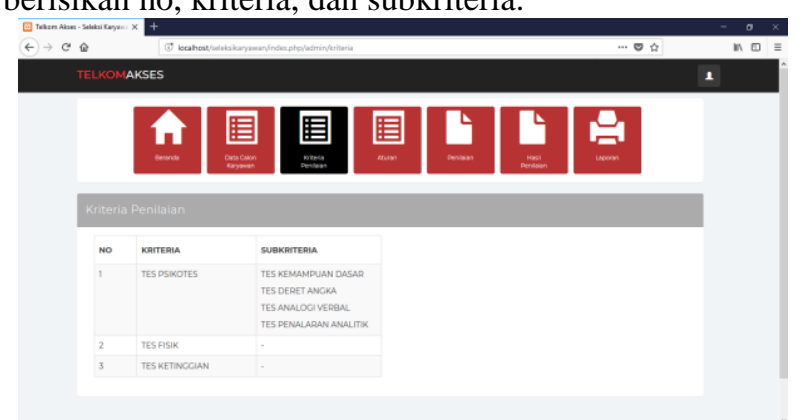

\section{Gambar 10. Tampilan Halaman Kriteria}

\subsection{Halaman Aturan}

Halaman Aturan merupakan halaman untuk menampilkan aturan fuzzy berisi nilai dari masingmasing kriteria penilaian serta keterangannya. Terdapat pilihan menu yaitu aturan tes psikotes dan tes hasil tes. Pada pilihan menu aturan menampilkan data berisikan no, k1, k2, k3, k4, dan keterangan. pada pilihan menu aturan hasil tes menampilkan data berisikan no, k1, k2, $\mathrm{k} 3$ dan keterangan.

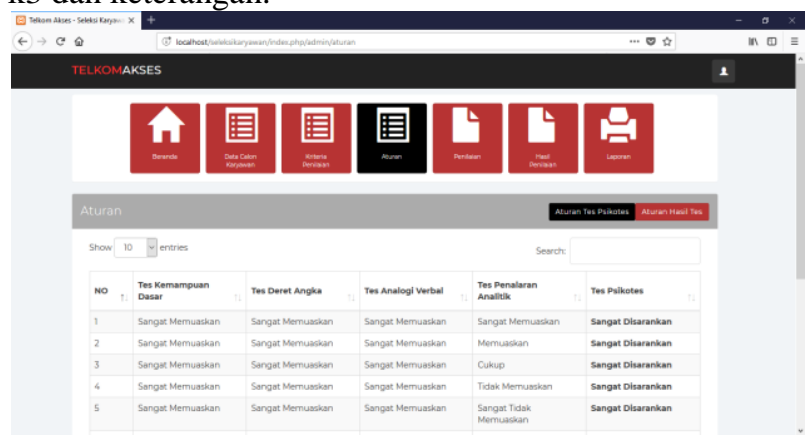

Gambar 11. Tampilan Halaman Aturan

\subsection{Halaman Penilaian}

Halaman untuk menampilkan nilai calon karyawan baru berdasarkan tanggal penilaian. Tombol input nilai untuk mengisi nilai calon karyawan dan tombol proses perhitungan fuzzy tsukamoto. Menampilkan data berisikan no, nik, nama, nilai tes kemampuan dasar, nilai tes deret angka, nilai tes analogi verbal, nilai penalaran analitik, nilai fisik, nilai ketinggian dan aksi yang berisi tombol sunting \& hapus. 


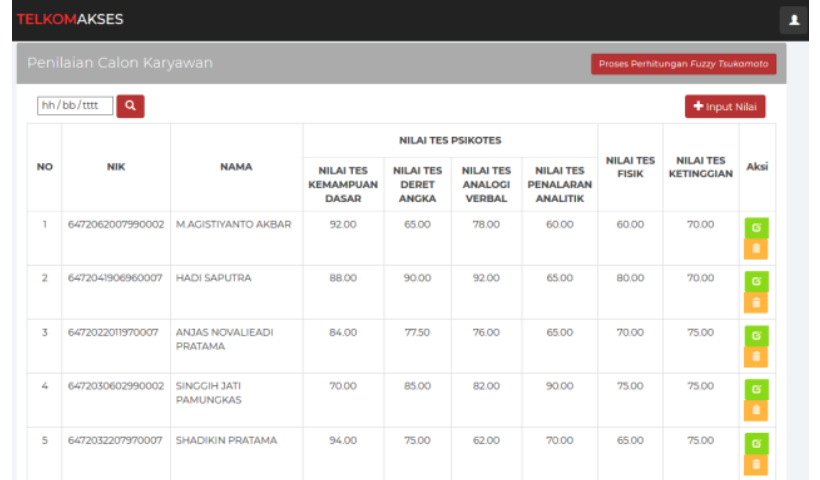

Gambar 12. Tampilan Halaman Penilaian

Halaman tambah nilai akan menampilkan form input pilih data calon karyawan yang akan di nilai, nilai tes kemampuan dasar, nilai tes deret angka, nilai tes analogi verbal, nilai penalaran analitik, nilai fisik, nilai ketinggian dan tombol simpan untuk menyimpan data yang di input ke database \& tombol kembali untuk kembali ke halaman penilaian.

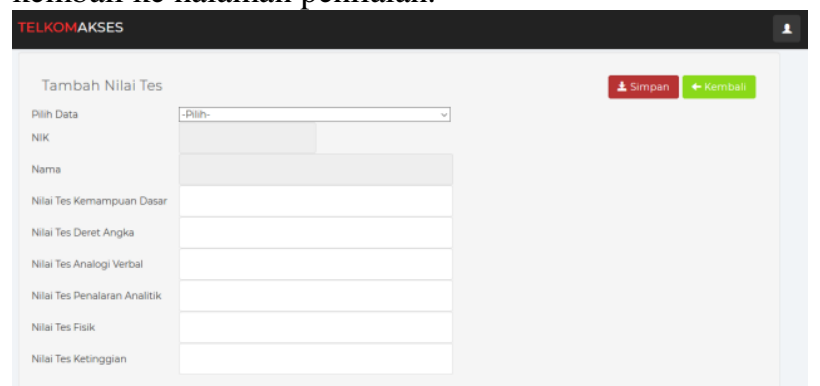

Gambar 13. Tampilan Halaman Tambah Nilai Tes

Jika nilai sudah diinputkan, pilih tombol proses perhitungan fuzzy tsukamoto untuk melakukan perhitungan. Hasil pada halaman ini akan tersimpan ke database.

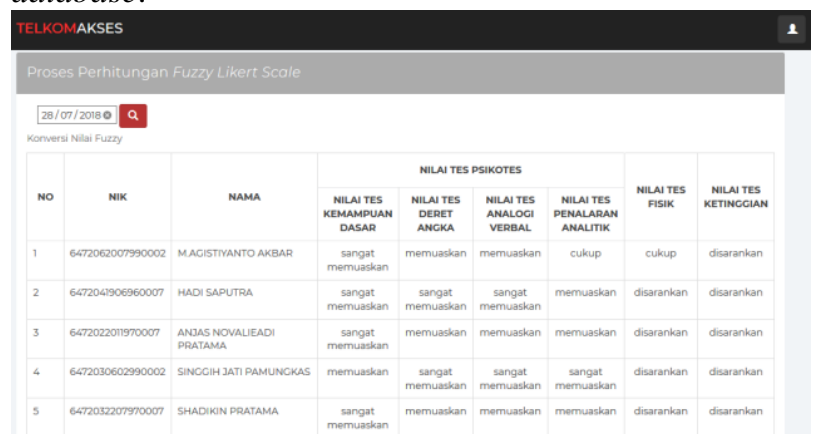

Gambar 14. Tampilan Halaman Proses Perhitungan Fuzzy Tsukamoto atas

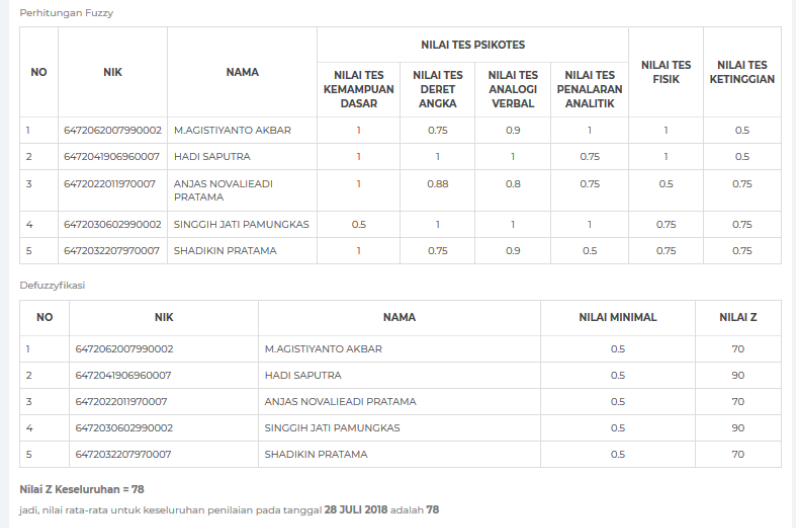

Gambar 15. Tampilan Halaman Proses Perhitungan Fuzzy Tsukamoto bawah

\subsection{Halaman Hasil Penilaian}

Halaman hasil penilaian merupakan halaman untuk menampilkan daftar hasil penilaian yang sudah dilakukan. Pada halaman ini memilih tanggal untuk memilih hasil penilaian sesuai dengan tanggal tes yang diambil dari database. Pada halaman ini data di urutkan dari nilai tertinggi ke yang terendah.

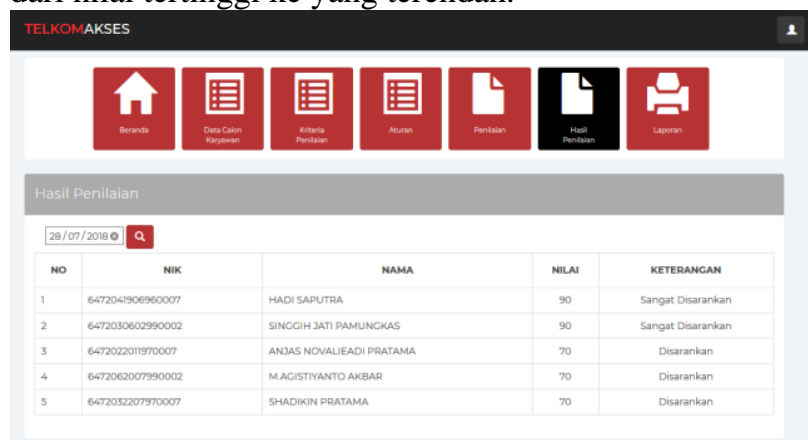

Gambar 16. Tampilan Halaman Hasil Penilaian

\subsection{Halaman Cetak Laporan}

Halaman ini untuk mencetak laporan data calon karyawan dan laporan penilaian hasil tes. Jika memilih tombol cetak daftar calon karyawan maka akan menampilkan laporan daftar calon karyawan yang diambil dari database. Jika memilih penilaian hasil tes tanggal yang berdasarkan tanggal nilai maka akan menampilkan laporan penilaian hasil tes yang diambil dari database.

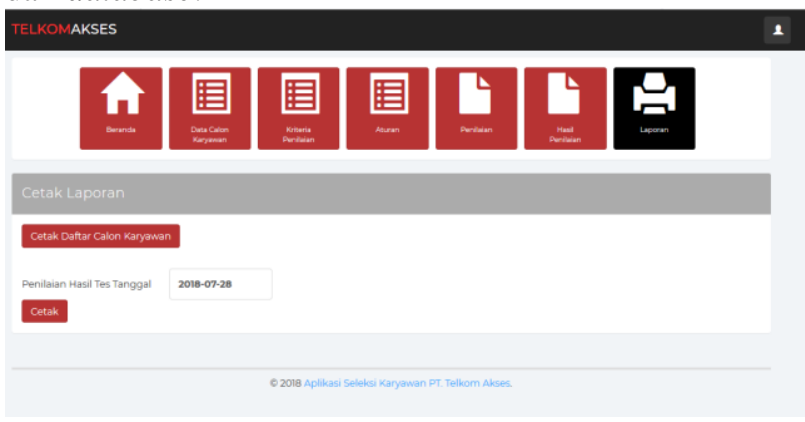

Gambar 17. Tampilan Halaman Cetak Laporan 


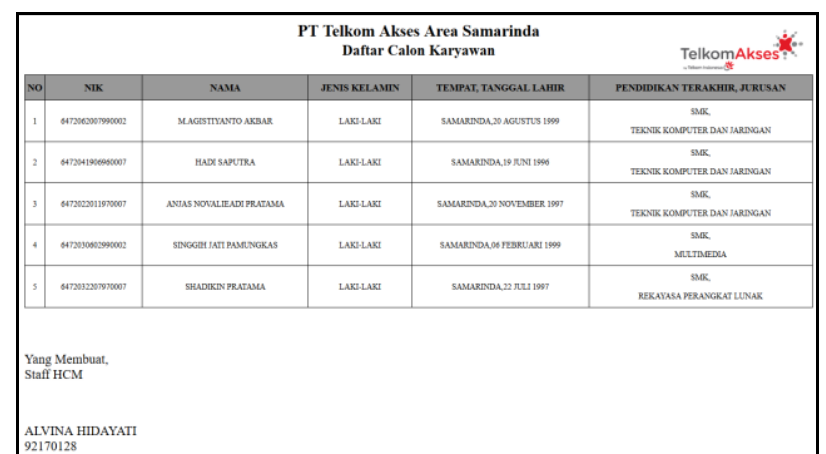

Gambar 18. Tampilan Laporan Daftar Calon Karyawan

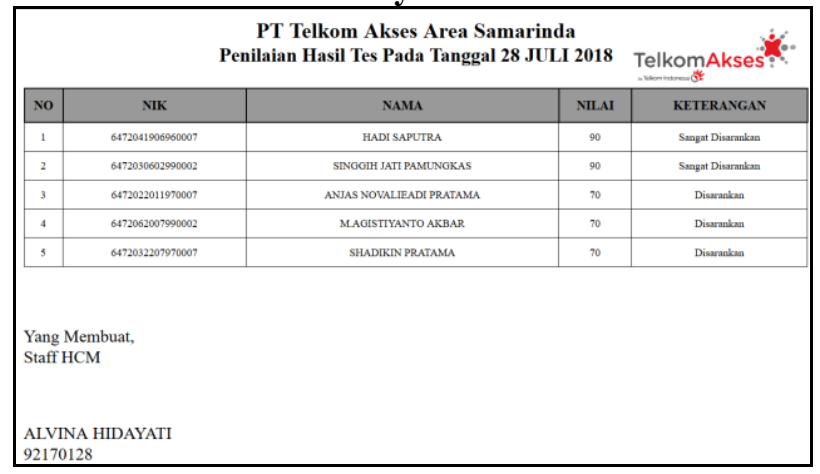

Gambar 19. Tampilan Laporan Penilaian Hasil Tes

\subsection{Halaman Manajemen Admin}

Pada halaman ini menampilkan data manajemen admin yang terkoneksi dari database. Menampilkan keterangan username, nama, jabatan, level, dan aksi sunting $\&$ hapus.

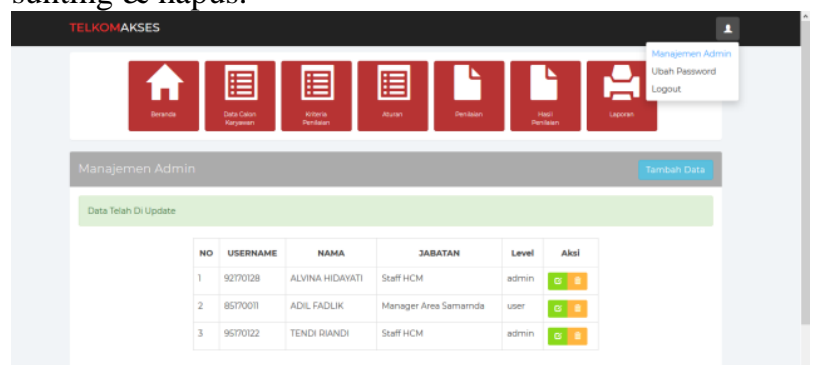

Gambar 20. Tampilan Halaman Manajemen Admin

\section{KESIMPULAN}

Implementasi skala likert seleksi karyawan baru dengan metode fuzzy tsukamoto pada PT Telkom Akses dengan cara mengumpulkan data kriteria penilaian, data likert scale. Lalu mengubah ke variabel fuzzy kemudian melakukan fuzzyfikasi menggunakan metode tsukamoto sehingga menghaslilkan rekomendasi penilaian hasil tes seleksi karyawan.

Dengan mengimplementasikan likert scale dengan fuzzy tsukamoto sebagai metode perhitungan pada sistem pendukung keputusan ini maka penilaian hasil tes calon karyawan bisa lebih detail dan akurat karena perhitungannya berdasarkan banyak variabel penilaian. Dapat menghitung fungsi keanggotaan masing-masing variabel tersebut serta dapat menentukan sangat disarankan atau tidaknya berdasarkan aturan sistem.

Hasil dari penilaian tes seleksi karyawan yang diperoleh dapat memberikan alternatif keputusan atau rekomendasi untuk menentukan calon karyawan yang terbaik untuk perusahaan.

\section{SARAN}

Berdasarkan dari kesimpulan yang telah dikemukakan diatas, maka penulis memberikan saransaran sebagai berikut:

1. Metode yang digunakan pada sistem ini adalah fuzzy likert scale menggunakan metode tsukamoto. Untuk pengembangannya nanti bisa menambahkan metode penilaian yang lain yaitu metode mamdani atau metode sugeno sehingga hasil penilaian dapat saling dibandingkan untuk memperkuat proses pengambilan keputusannya.

2. Sistem ini dapat dikembangkan dengan dihubungkan langsung kepada aplikasi tes online perusahaan.

\section{DAFTAR PUSTAKA}

Anhar. 2010. Panduan Menguasai PHP dan MYSQL Secara Otodidak. Jakarta: Mediakata.

Arief, M. Rudyanto. 2011. Pemrograman Web Dinamis Menggunakan PHP \& MYSQL. Yogyakarta: Andi Offset

Chaffey, D. 2011. E-Business and E-Commerce Management : Strategy, Implementation, and Practice (5 th ). Pearson Education

Djaali. 2008. Skala Likert. Jakarta: Pustaka Utama.

Fitriyani. 2012. Sistem Pendukung Keputusan Penjurusan Sma Menggunakan Metode AHP. Seminar Nasional Teknologi Informasi \& Komunikasi Terapan 2012 (Semantik 2012). ISBN 979 - 26 - 0255 - 0. Jurusan Sistem Informasi, STMIK Atma Luhur Pangkalpinang.

Hakim, L. 2009. Jalan Pintas Menjadi Master PH. Yogyakarta: Lokomedia.

Indrajani. 2015. Database Design (Case Study All in One). Jakarta: PT Elex Media Komputindo.

Kusumadewi, S., \& Purnomo, H. 2009. Aplikasi Logika Fuzzy untuk Pendukung Keputusan. Yogyakarta: Graha Ilmu.

Madcoms, Andi. 2010, Adobe Dreamweaver CS5 dengan Pemrograman PHPMySQL. Yogyakarta: Andi Offset.

Nugroho, Adi. 2010. Rekayasa Perangkat Lunak Menggunakan UML dan JAVA. Yogyakarta: Andi Offset.

Parewe, A. M. A. K., \& Mahmudy, W. F. 2016. Seleksi Calon Karyawan menggunakan Metode Fuzzy Tsukamoto. Skripsi, Jurusan Ilmu Komputer, Malang: Universitas Brawijaya

Pressman. S, 2010. Rekayasa Perangkat Lunak : Pendekatan Praktisi, Yogyakarta : Andi

Rivai, Veithzal. 2011, Manajemen Sumber Daya 
Manusia untuk Perusahaan: dari Teori ke Praktik. Jakarta : RajaGrafindo Persada.

Riyuna. 2017. Sistem Pendukung Keputusan Penilaian Kinerja Pegawai Menggunakan Metode Fuzzy Tsukamoto Berbasis Web. Skripsi, Jurusan Sistem Informatika, Samarinda: Stmik Widya Cipta Dharma.

S, Rosa A., \& Shalahuddin, M. 2013. Rekayasa Perangkat Lunak Terstruktur dan Berorientasi Objek. Bandung : Informatika.

Siagian, Sondang P. 2013. Manajemen Sumber Daya Manusia. Jakarta: PT Bumi Aksara.

Simarmata, Janner. 2010. Rekayasa Web. Yogyakarta: Andi Offset.

Sugiyono. 2012. Metode Penelitian Kuantitatif, Kualitatif dan $R \& D$. Bandung: PT Alfabeta.

Utami, Winda Pangesti. 2012. Penerapan Algoritma Iterative Dichotomiser Three untuk Pemilihan Dosen Pembimbing. Universitas Kristen Satya Wacana: Jawa Tengah.

Vonglao, Paothai. 2017. Application of fuzzy logic to improve the Likert scale to measure latent variables. Jurnal, Faculty of Science, Thailand: Ubon Ratchathani Rajabhat University, Ubon Ratchathani 34000.

Wahyono, Teguh. 2009. Sistem Informasi (Konsep Dasar, Analisi, Desain dan Implementasi). Graha Ilmu : Yogyakarta

Wibowo, Bagus Ari. 2011. Perancangan dan Implementasi Sistem Pendukung Keputusan untuk Jalan Menggunakan Metode ID3 (Studi Kasus BAPPEDA Kota Salatiga). Universitas Kristen Satya Wacana: Jawa Tengah

Wicaksono, Yogi. 2008. Membangun Bisnis Online dengan Mambo. Jakarta: PT. Elex Media Komputindo

Yuhefizar, 2009, Cara Mudah Membangun Website Interaktif Menggunakan Content Managemen System Joomla (CMS), Jakarta : Elex media computindoHanif, Al Fatta. 2007, Analisis dan Perancangan Sistem Informasi. Yogykarta: Andi. 